\title{
Double Staining in Rats (Mini Review)
}

\author{
Seher Yilmaz* and Adem Tokpınar \\ Department of Anatomy, Yozgat Bozok University Faculty of Medicine, Turkey \\ *Corresponding author: Seher Yilmaz, Department of Anatomy, Faculty of Medicine, Turkey
}

\begin{abstract}
ARTICLE INFO
Received: 慧 March 27, 2019

Published: April 03, 2019

Citation: Seher Yilmaz. Double Staining in Rats (Mini Review). Biomed J Sci \& Tech Res 16(4)-2019. BJSTR. MS.ID.002899.

\section{ABSTRACT}

The double skeleton staining method is among the methods which are particularly used on rats. In the literature, studies take place titled as the examination of the effects on fetus bones by giving various substances on pregnant rats. Two different types of ossification are described in the embryonic period called as intramembranous ossification and endochondral ossification. Different staining methods are used to determine this ossification. Studies in which binary skeletal staining have been used are formed in two groups as teratogenic studies and developmental studies.
\end{abstract}

Keywords: Double Staining; Ossification; Rat; Bone Mineral Density; Fetus

\section{Introduction}

Double skeleton staining method is among the method which is used in the studies of literature. Generally, examination of the possible effect on fetus bones in pregnant rats is included in the studies which have been carried out [1]. The process of staining the bones and cartilage, which form the skeleton, with different stains in different colors or in different shades of the same colour is called double skeleton staining. The studies in which double skeleton staining have been used are collected in two groups as teratogenic studies and developmental studies. In teratogenic studies, the effects of various chemical substances or physical factors on the skeletal system and the fetus of experimental animals preferred in teratogenic studies are examined in the skeletal system by double skeletal staining at different stages of their development [2]. In developmental studies, double skeleton staining is performed on human embryos and fetus obtained as a result of abortus and the relation between bone and cartilage areas in different bones and age of fetus, ossification in other bones, etc.is examined [3,4]. Two different types of ossification, called intramembranous ossification and endochondral ossification, are defined in the embryonic period $[1,5]$. Intramembranous ossification: This type of ossification usually observed in flat bones. In areas where intramembranous ossification will occur; mesenchyme intensifies and begins to vascularize. There is no regular structure in the first formed bone. Bone, which are organized in time, gain a structure of lamellae. The lamellae structure formed around the blood vessels, while creating the Havers systems, the osteoblasts around the developing bone structures constitutes compact bone layers [6,7].

\section{Endochondral Ossification}

In this type of ossification, a cartilage model is formed primarily in the area where the bone will form. Then this cartilage model is eliminated by replacing the bone tissue. With this type of ossification, long and short bones are formed. In both types of ossification, the first bone tissue is the primary or immature bone tissue. Then the Primary bone tissue is replaced by secondary bone tissue [8]. Skeletal development in rats: At the end of the $9^{\text {th }}$ day of embryonic life or in the beginning of the $10^{\text {th }}$ day in rats, somit development starts. At the end of the $11^{\text {th }}$ day there 25 , on the $13^{\text {th }}$ day 45 and on the $16^{\text {th }}$ day 65 somit appear. From the $16^{\text {th }}$ day onwards, the first ossification centers occur. The first ossification centers are seen in the clavicula, ribs and some bones of the skull. On the $16^{\text {th }}$ day, the spaces of the hip, knee, shoulder and elbow joints begin to become clear and the vessels anlage fuse. On the $17^{\text {th }}$ day, the ossification is disseminated to the extremity buds and other bones of the skull while the spaces of the wrist and ankle joints become evident. On the $18^{\text {th }}$ day the head grows rapidly and the palate drafts fuse. On the $19^{\text {th }}$ and $20^{\text {th }}$ days the spaces of the finger joints of the anterior and posterior extremities are seen. Birth occurs on the $22^{\text {nd }}$ day in rats [7-10]. In a new born rat, the trunk and diaphysis of the long 
bones are largely ossified, but the epiphyses are still in the cartilage structure. Most secondary ossification centers continue to exist in the days following birth [11-13]. Rat skeletal system: The skeletal system are examined by dividing into two parts as skeleton axiale and skeleton appendicular [14,15]. 1.Skeleton axiale: Columna vertebralis, which forms the body axis, consists of vertebralis, rib cage and skull bones. Skull bones: consist of a total of 28 bones; some of them are single while some of them are paired [10-14]. Spine: The rat spine consists of 7 cervical, 13 thoracic, 6 lumbal, 4 sacral and caudal (tail) vertebras ranging from 25 to $30[16,17]$.

\section{Method}

\section{Double Staining Process}

In order to stain the skeletal system of fetus with double skeleton staining method; all fetus is kept in 70\% ethyl alcohol for 4-7 days and the water is provided to be absorbed. Fosllowing this process, they are kept in pure acetone for 1-3 days and they are purified from fats. Then the skin is removed. During all of these procedures, the number of experimental animals should be kept high in case some fetus has limb ruptures and bone tissue injuries. Damaged subjects are not stained. By peeling off the skin and removing the internal organs and the eyes for staining, the staining process of the skeleton of the fetus and the pups is carried out in accordance with the protocol described below in Table 1. Preparation of Stain Solution: Stain solution is obtained by combining the solutions prepared separately with specific methods.

Preparation of solutions:

a) Solution 1: It is obtained by stirring and melting $300 \mathrm{mg}$ of Alcian Blue constantly in $100 \mathrm{ml}$ of $70 \%$ ethyl alcohol.

Table 1: Double Skeletal System Staining Method.

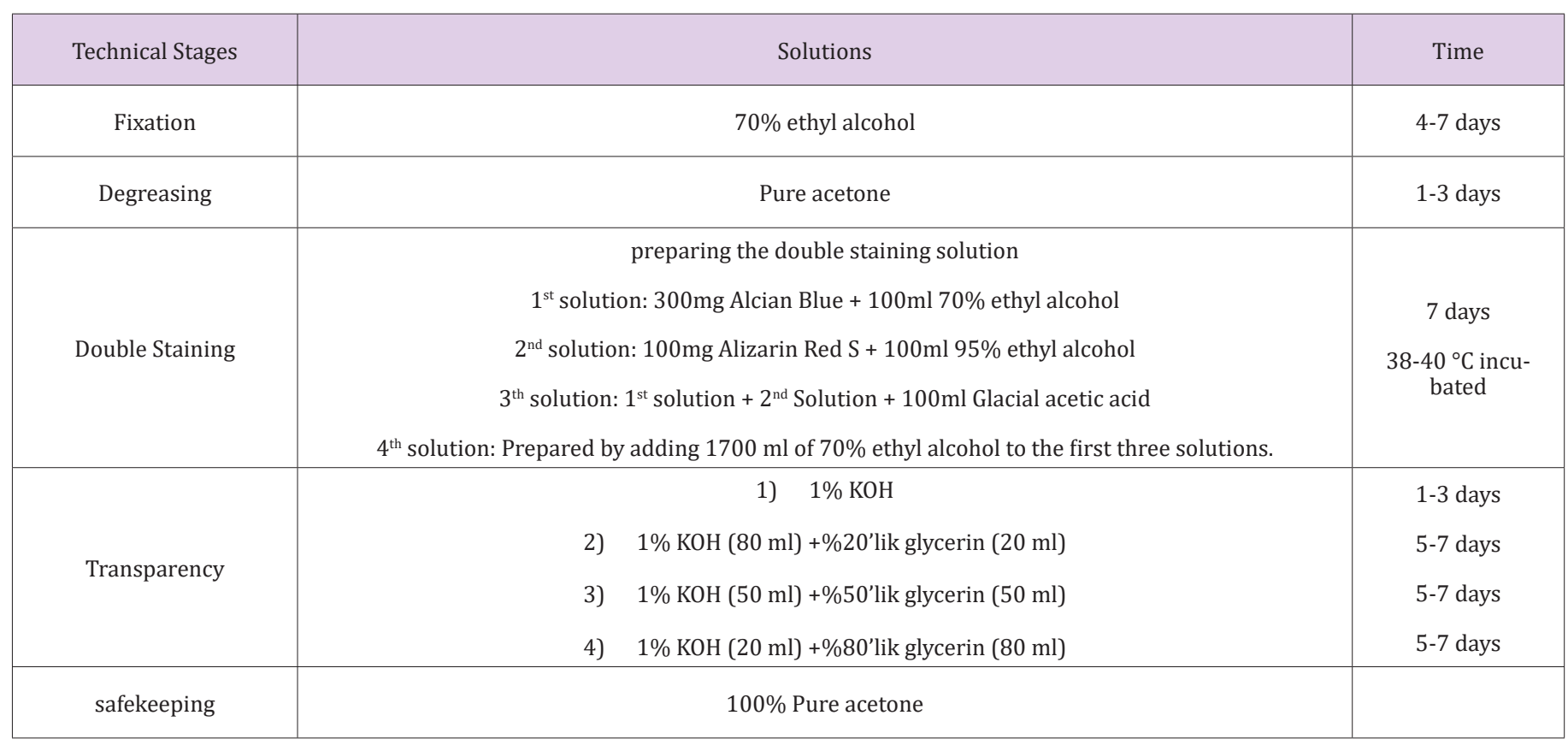

b) Solution 2: It is obtained by stirring and melting $100 \mathrm{mg}$ Alizarin Red-S constantly in $100 \mathrm{ml}$ of $95 \%$ ethyl alcohol.

c) Solution 3: It is obtained by adding the second solution gradually into the first solution which has been prepared beforehand. After complete mixing of these two solutions, 100 $\mathrm{ml}$ of Glacial Acetic Acid is added to this mixture.

d) Solution 4: It is prepared by adding $1700 \mathrm{ml}$ of $70 \%$ ethyl alcohol into the prepared third solution.

\section{Staining Process}

The tissues of the fetus and pups are provided to be stained in the stain solution prepared according to the method described above, by being kept in the oven at $38-40^{\circ} \mathrm{C}$ for 7 days. At the end of this period, the fetus is washed under running tap water for 2 hours to have them reacted with water. Then, the process of transparency proceeds. Transparency phase: It consists of 4 stages.

a) Stage 1: The stained fetus is soaked in $1 \% \mathrm{KOH}$ for 1 day.

b) Step 2: For 5 days, they are soaked in the mixture of $80 \mathrm{ml}$ of $1 \% \mathrm{KOH}$ and $20 \mathrm{ml}$ of $20 \%$ glycerin.

c) Step 3: For 5 days, they are soaked in the mixture of $50 \mathrm{ml}$ of $1 \% \mathrm{KOH}$ and $50 \mathrm{ml}$ of $50 \%$ glycerin.

d) Step 4: They are soaked in $20 \mathrm{cc} 1 \% \mathrm{KOH}$ and $80 \mathrm{ml}$ of $80 \%$ glycerin solution in for 5-7 days.

After these stages, the bone cartilage ratio is calculated in Alcian Blue, and Alizarin Red S-stained fetus bones (Figure 1). 


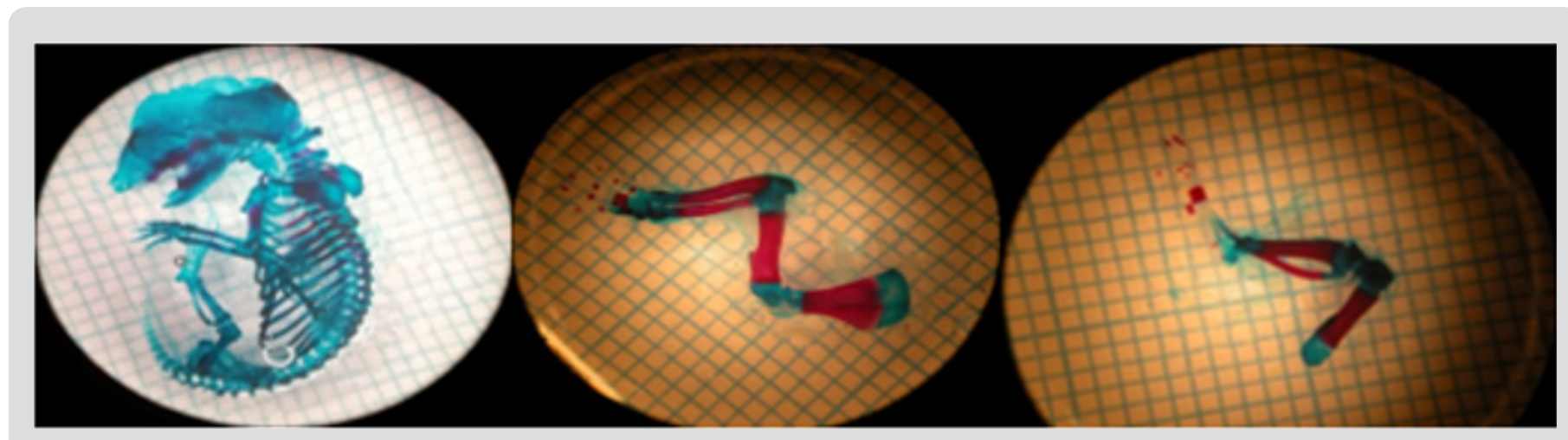

Figure 1: Bone cartilage appearance of rat fetus treated with double skeleton staining. The areas stained with blue indicate cartilage and red areas show ossification.

\section{Discussion}

In many studies conducted in the literature, different stains have been used in double staining methods and the aim is to provide different colours of bone and cartilage. Teratogenic studies are usually available on pregnant Ratsn Yilmaz 2018; Güneş 2011; Tizabi 2000. In their studies, the pregnant rats have been given different doses of nicotine. In their study, they reported the variability of bone and cartilage ratios in fetus by using double skeleton staining method [1,18,19]. Yllmaz (2018) investigated the protective effects of melatonin against the effects of nicotine on bones in their study; and they used double staining method in their study. They found that the percentage and rate of ossification was low in the upper and lower extremity bones of the group [1]. Kurtoglu (2007) investigated the negative effects of nicotine on bone development. In their study they used double staning method and they administered $3 \mathrm{mg} / \mathrm{kg}$ nicotine given i.p during pregnancy and lactation [20]. Hu (2018) evaluated the osteoclast genesis and endochondral ossification of long bones of fetuses in pregnant rats exposed to nicotine they used double staining skeletal method [21]. In their study, Tomaszewski et al, reported with the double staining method that they had common abnormalities related to the most deteriorated mineralization of bone tissue in fetus of pregnant rats which have been given caffeine [22].

\section{Conclusion}

One of the methods used in many studies is the double skeleton staining method. When literature is examined, many publications in this area especially in determining teratogenic effect can be seen. In many of our studies, we have used the double skeleton staining method. We believe that this study will be instructive by contributing the literature in terms of specifying the method more clearly.

\section{References}

1. Salford LG, Brun AL, Eberhardt JL, Malmgren L, Persson BR (2003) Nerve cell damage in mammalian brain after expose to microwawes from GSM mobile phones. Enviromental Health Perspectives 111(7): 881-883.

2. Bolat F, Eren Ö, Bolat G (2012) Maternal Smoking During Pregnacy and Effects on Neonatal Antropometry: a Prospective study. Turk J Med Sci 42(6): 999-1005.
3. Yllmaz HT, Ertekin E, Atay M, Nisari H, Güler Ö, et al. (2018) Antioxidant role of melatonin against nicotine's teratogenic effects on embryonic bone development. Iran J Basic Med Sci 21(8): 787-793.

4. Odacı E, Bas O, Kaplan S (2008) Effects of prenatal exposureto a 900 $\mathrm{MHz}$ electromagnetic field on the dentate gyrus of rats; a stereo logical and histo pathological study. Brain Research 1238: 224-229.

5. Junqueira LC, Carneiro J (2006) Basic Histology. Nobel Tip Kitapevleri İstanbul pp. 135-155.

6. Mehmet B, Özgün S, Serap Y, Ülkü Ç, Fatma S, et al. (2017) The Investigation of Impact of Stronsium Ranelat Application on Paraoxonase and Arylesterase Activities in Liver, Kidney and Muscle Tissues in Experimental Osteoporosis Rat Model. Van Medical Journal 24(1): 1218.

7. Soylu SM (2017) Rat Fizyolojisi. Journal of Clinical and Analytical Med p: 22-25.

8. Sharp PE, La Regina MC, Suckow MA (1998) The laboratory rat. CRC Pres p: 16.

9. Whishaw IQ Bergdall V, Kolb B (2006) Analysis of behaviour in laboratory rats. In: Suckow MA, Weisbroth SH, Franklin CL (Eds.), (2 $2^{\text {nd }}$ edn.). The laboratory rat Academic Press pp:191-218.

10. Jain NC (1993) Essentials of Veterinary Hematology. Lea \& Febiger Philadelphia p. 69.

11. Asadi E, Jahanshahi M, Golalipour M (2012) Effects of Vitamin E on Oocytes Apoptosis in Nicotine-Treaded Mice. Iranian Journal of Basic Medical Sciences (15)3: 880-884

12. Chin K, Ima Nirwana S (2015) The Bilogical Effects of Tocotrienol on Bone: A Review on Evidence from Rodent Models. Drug Design, Development and Therapy 9: 2049-2061.

13. Moore KL, Persaud TVN (2002) Human Embriyology (6 edn.). Çeviri: Yıldırım M, Okar İ, Dalçık H, Kitap: Klinik Yönleri İle İnsan Embriyolojisi. Nobel Tıp Kitapevleri, İstanbul pp. 453-477.

14. Bașaran A, Sarıbay A, Akın S (2005) Kafein ve Kemik Mineral Yoğunluğu İlişkisi. Türk Geriatri Dergisi 8(2): 61-68.

15. Baştuğ O (2005) Gebelik ve Laktasyonda Nikotin veya NikotinPentoksifilin Aliminin Yavru Rat Kemik Gelişimine Etkileri, Tıpta Uzmanlık Tezi, Erciyes Üniversitesi Tıp Fakültesi, Kayseri.

16. Soysal H, E Unur, A Düzler, Ö Karaca, N Ekinci (2011) Effects of intraperitoneal administration of the phenytoin on the skeletal system of rat fetus. Seizure 20(3): 187-193.

17. Shrader RE, Zeman FJ (1993) Skeletal Development in Rats as Affected by Maternal Protein Deprivation and Postnatal Food Supply. The Journal of Nutrition 103(5): 792-801. 
18. Güneș T, Akın M, Canoz O (2011) Aortic Intima-Media Thickness in Nicotine-Exposed Rat Pups During Gestation and Lactation Period. Eur J Pediatr 170(10): 1257-1262

19. Tizabi Y, LT Russell, SM Nespor, DC Perry, NE Grunberg (2000) Prenatal nicotine exposure: effects on locomotor activity and central [125I] alpha-BT binding in rats. Pharmacol Biochem Behav 66(3): 495-500.

20. Kurtoglu S, T Gunes, E Koklu, O Bastug, O Canoz, et al. (2007) Influence of maternal nicotine exposure on neonatal rat bone: protective effect of pentoxifylline. Exp Biol Med 232(3): 398-405.

\section{ISSN: 2574-1241}

DOI: 10.26717/BJSTR.2019.16.002899

Seher Yilmaz. Biomed J Sci \& Tech Res

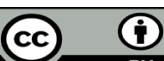

This work is licensed under Creative Commons Attribution 4.0 License

Submission Link: https://biomedres.us/submit-manuscript.php
21. Hu H, X Zhao, M Jing, Y Shangguan, Z Pan, et al. (2018) Prenatal nicotine exposure retards osteoclastogenesis and endochondralossification in fetal long bones in rats. Toxicology Letters 17: 249-255.

22. Tomaszewski M, Olchowik G, Tomaszewska M, Dworzański W, Pańczuk A, et al. (2014) Influence of caffeine administered at $45^{\circ} \mathrm{C}$ on bone tissue development. Annals of Agricultural and Environmental Medicine 21: 804-809.

$\begin{array}{ll}\text { BIOMEDICAL } & \text { Assets of Publishing with us } \\ \text { RESEARCHES } & \text { - Global archiving of articles } \\ \text { - Immediate, unrestricted online access } \\ \text { - Rigorous Peer Review Process }\end{array}$

